\title{
DETERMINATION OF FLUORIDES IN FEEDING PHOSPHATES
}

\author{
O. SYNEK, E. ŠUCMAN, M. SUCMANOVÁ
}

\author{
Department of Chemistry, Physics and Biochemistry, University of Veterinary Science, \\ 61242 Brno
}

Received October 9, 1978

\begin{abstract}
Synek O., E. Sucman, M. Sucmanová: Determination of Fluorides in Feeding Phosphates. Acta vet. Brno, 47, 1978: 159-162.

A method was elaborated of the determination of fluorides in mineral feeding phosphates using the fluoride ion selective electrode. The following average contents of fluoride were determined using this method: $0.07-1.80 \mathrm{~g} \mathrm{~kg}^{-1}$ in dicalciumphosphates, $0.22-2.47 \mathrm{~g} \mathrm{~kg}^{-1}$ in dinatriumphosphates, $1.97-3.86 \mathrm{~g} \mathrm{~kg}^{-1}$ in pyrophosphates, and $0.21 \mathrm{~g} \mathrm{~kg}^{-1}$ in ammoniumdihydrogenphosphate. This method of determination is quick, simple and sufficiently accurate. It can be used for controlling the content of fluoride in mineral feeding phosphates.
\end{abstract}

Feed mixtures, sources of fluorine, fluoride ion selective electrode.

Nutrition of farm animals under conditions of modern agricultural large-scale production has become unthinkable without commercially produced feed mixtures of different kinds. A very important component of these feed mixtures are also mineral feeding phosphates which sometimes represent as much as one tenth of the weight of the mixture. These phosphates are necessary both for supplying the organism of farm animals with a sufficient amount of phosphorus and for the optimization of the phosphorus/calcium ration in the feed ration. Along with the optimum composition of feed mixtures it is important to control the purity of their individual components. In feeding phosphates it is namely the content of fluorides which are a natural component of raw materials used for their production.

According to Schwarz (1974) fluorine ranks among the essential elements. It stimulates namely the growth of the organism and the development of bones (Schwarz 1974), and it also effects the activity of some enzymes (Ros en quist 1975). On the other hand, however, an excessive uptake of fluorine leads to intoxication. While cases of acute poisoning are not frequent, it is a well known fact that a long-term excessive uptake of fluorine causes fluoroses. In such cases irreversible changes occur, especially in the bone tissue, in younger animals also in teeth (Jagoš et al. 1977). Secondarily, the whole performance of the animals is affected. The maximum admissible amount of fluorine (as fluoride) in feeds for cattle is, according to Greenwood et al. (1964) about $50 \mathrm{mg} \mathrm{kg}{ }^{-1}$; according to Hapke (1975) it is $40 \mathrm{mg} \mathrm{kg}^{-1}$, in sheep less than $10 \mathrm{mg} \mathrm{kg}^{-1}$. Griffith-Jones (1977) tolerates $60-100 \mathrm{mg} \mathrm{kg}^{-1}$ for dairy cows. According to results of Said et al. (1977) fluorine even in such a small amount as $30 \mathrm{mg} \mathrm{kg}^{-1}$ causes serious changes in the bone tissues of rams.

The fluoride ion selective electrode method has much simplified fluoride determination which had always been very time and labour consuming and represents, at the present time, an accessible means for a simple determination of this element. With regard to the fact that mineral feeding phosphates are a permanent component of nutrition of farm animals, they represent a potential source of excessive flow of fluorides into the organism. That is why a method of fluoride determination was elaborated using the ion selective electrode and in the commonly applied mineral feeding phosphates this method was used for the determination of the fluoride content.

\section{Materials and Methods}

The fluoride content was determined in formulas of dicalciumphosphates imported to Czechoslovakia in the period of $1975-1977$ as feeding mineral admixtures. Dinatriumphosphate and pyrophosphate were produced in 1976-1977 in the national enterprise FOSFA in Poštorná, ammo- 
niumdihydrogenphosphate was produced in the national enterprise SYNTHESIA in Pardubice.

Determination was performed using the fluoride ion selective electrode CRYTUR, type 09-17 of the firm MONOKRYSTALY in Turnov on the Digital Ionalyzer Model 801A apparatus of the firm ORION RESEARCH. A saturated calomel electrode $\mathrm{K} 401$ of the firm RADIOMETER served as a reference electrode.

All the chemicals used were of a p. a. purity of the firm LACHEMA. Deionized water was used for the preparation of the solutions.

Stock solutions of fluoride standards were kept in polyethylene containers. An acetate buffer $(\mathrm{pH}-5.5)$ with an addition of Chelaton 4 for masking the interferring ions was used for maintaining a suitable $\mathrm{pH}$ and the ion strength of the solutions measured and working standards. The determination was performed using the method of standard addition. The concentration of standard solutions ranged between $1.10^{-4} \mathrm{M}$ and $5 \cdot 10^{-12} \mathrm{M}$ and was dependent on the amount of fluoride in the solution measured.

Samples of dinatriumphosphate and ammoniumdihydrogenphosphate in amounts of $1 \mathrm{~g}$ were dissolved in $100 \mathrm{ml}$ of deionized water. For the determination of fluorides in pyrophosphate $0.5 \mathrm{~g}$ of the sample was dissolved in $20 \mathrm{ml}$ of water with $2 \mathrm{ml}$ of $2 \mathrm{~N}$ nitric acid. After dissolving the solution was completed to a volume of $100 \mathrm{ml}$. An amount of $0.2 \mathrm{~g}$ of dicalciumphosphate was dissolved in $5 \mathrm{ml}$ of $1 \mathrm{~N} \mathrm{HCl}$ and this solution was filled up to $100 \mathrm{ml}$. From solutions prepared in such a way an equivalent portion was taken for the determinations which contained $1-50 \mathrm{mg}$ of fluorides.

The results obtained were statistically elaborated in the usual way.

Table 1

Fluoride contents in various types of feeding phosphates

\begin{tabular}{|c|c|c|c|c|c|}
\hline Sample & 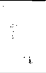 & Producer & $\begin{array}{c}\bar{x} \\
\mathrm{k} \mathrm{kg}^{-1}\end{array}$ & $\begin{array}{c}95 \% \mathrm{CI} \\
\mathrm{g} \mathrm{kg}^{-1}\end{array}$ & $n$ \\
\hline Dicalciumphosphate & & CKF & 1.77 & 1.748 to 1.792 & 3 \\
\hline Dicalciumphosphate & & $\begin{array}{l}\text { Sojuzchimexport } \\
\text { (USSR) }\end{array}$ & 0.07 & 0.0697 to 0.0703 & 3 \\
\hline Dicalciumphosphate & & Kuhlman & 1.80 & 1.768 to 1.832 & 3 \\
\hline Dinatriumphosphate & & Fosfa & 2.47 & 2.364 to 2.576 & 7 \\
\hline Dinatriumphosphate & & $\begin{array}{l}\text { Fosfa } \\
\text { (CSSR) }\end{array}$ & 0.95 & 0.942 to 0.958 & 4 \\
\hline Dinatriumphosphate & & Fosfa & 0.22 & 0.209 to 0.231 & 6 \\
\hline Dinatriumphosphate & & $\begin{array}{l}\text { Fosfa } \\
\text { (CSSR }\end{array}$ & 1.10 & 1.097 to 1.103 & 8 \\
\hline Pyrophosphate & & $\begin{array}{l}\text { Fosfa } \\
\text { (CSSR) }\end{array}$ & 3.33 & 3.093 to 3.567 & 4 \\
\hline Pyrophosphate & & $\begin{array}{l}\text { Fosfa } \\
\text { (CSSR) }\end{array}$ & 1.97 & 1.746 to 2.194 & 3 \\
\hline Pyrophosphate & & $\begin{array}{l}\text { Fosfa } \\
\text { (CSSR) }\end{array}$ & 2.81 & 2.607 to 3.013 & 4 \\
\hline Pyrophosphate & & Fosfa & 3.86 & 3.631 to 4.089 & 3 \\
\hline Ammoniumdihydrogenphosphate & & $\begin{array}{l}\text { Synthesia } \\
\text { (CSSR) }\end{array}$ & 0.21 & 0.194 to 0.226 & 5 \\
\hline
\end{tabular}

Explanations:

$\bar{x}-$ average content of fluorides found in sample

$95 \% \mathrm{CI}-95 \%$ configence interval for fluoride content in sample given $n$ - number of determinations

\section{Results}

Tab. 1 gives the contents of fluorides found in various types of feeding phosphate The lowest content of fluorides $\left(70 \mathrm{mg} \mathrm{kg}^{-1}\right)$ in dicalciumphosphate was found in the sample imported by Soyuzkhimexport. This content also represents the lowest value determined in all types of phosphates analyzed. Four samples of dinatriumphosphate come from various production charges and the contents of fluorides found ranged from 0.22 to $2.47 \mathrm{~g} \mathrm{~kg}^{-1}$. In samples of pyrophosphates 
the fluoride content ranged from 1.97 to $3.86 \mathrm{~g} \mathrm{~kg}^{-1}$. The average content in the sample of ammoniumdihydrogenphosphate analyzed was $0.21 \mathrm{~g} \mathrm{~kg}^{-1}$.

Due to the unhomogeneity of the material Tab. 1 shows, apart from the average content found, also the $95 \%$ confidence interval which enables a better evaluation of the content of fluoride determined in the given sample.

\section{Discussion}

The elaborated method of determination of the fluoride content in mineral feeding phosphates enables an easy control of their purity. The accuracy of the results achieved was proved using two methods. In the recovery test the yields reached ranged from $97.6 \%$ to $103.6 \%$ in all the types of samples analyzed. Besides, the results achieved by measuring using the ion selective electrode were in very good accordance with results of determination using the distillation photometric method modified according to $\mathrm{T} u$ šl (1968). In pyrophosphate $0.395 \%$ of $\mathrm{F}^{-}$ was found using the distillation photometric method, $0.386 \%$ using the ion selective electrode. It was similar for the sample of dinatriumphosphate, i. e. $0.112 \%$ of $\mathrm{F}^{-}$using the ion selective electrode and $0.118 \%$ of $\mathrm{F}^{-}$using the distillation photometric method. The precision of the method expressed using the relative standard deviation ranged around $5 \%$.

Under normal conditions outside the region of industrial exhalations the various kinds of feeds and water represent the main source of fluorine transferred into the organism of animals. Vandeputte et al. (1976) found that the content of fluorides in wheat, barley and oats straw ranged from 111.1 to $918.8 \mathrm{mg} \mathrm{kg}^{-1}$, in hay as much as $600 \mathrm{mg} \mathrm{kg}^{-1}$. Davidson et al. (1976) dealt with the content of fluorides in green fodder on pastures for cattle and found a correlation between the amount of fluorides and the effects of the weather, especially of rainfall. In their studies the content of fluoride for green fodder amounted to $36-98 \mathrm{mg} \mathrm{kg}^{-1}$ (in dry matter).

Torma (1975) analyzed various types of feed mixtures with a low and high proportion of mineral admixtures and found that the content of fluorides ranged from 0.78 to $5.05 \mathrm{~g} \mathrm{~kg}^{-1}$.

The contents of fluorides in superphosphates are higher. Tušl (1970) determined $18.1 \mathrm{~g} \mathrm{~kg}^{-1}$ in superphosphate and $11.3 \mathrm{~g} \mathrm{~kg}^{-1}$ in defluorinated superphosphate. Laing (1976) found that the content of fluorides in superphosphate ranged around $15 \mathrm{~g} \mathrm{~kg}^{-1}$.

Our values are in good accordance with the values found by Tušl (1970) for some types of phosphates. While the results for dicalciumphosphate can be considered to be of an orientation character only, because of the small number of samples, the results for dinatriumphosphate and pyrophosphate roughly include the range for the fluoride content in these substances produced in the national enterprise Fosfa. This fact was proved when elaborating further samples from randomly selected production charges.

The elaborated method of determination of fluorides using the ion selective electrode is a simple, quick and accessible means for the control of the purity of feeding phosphates; this can be useful as regards the biological importance of fluorine as it seems that these substances represent one of the main sources of fluorine for the organism of farm animals. 


\section{Stanovení obsahu fluoridů v krmných fosfátech}

Byla vypracována metoda stanoveni obsahu fluoridů $\mathrm{v}$ minerálních krmných fosfátech pomocí fluoridové iontově selektivní elektrody. Touto metodou byly dále stanoveny následující průměrné obsahy fluoridů: $\mathbf{v}$ dikalciumfosfátech $0.07-1,80 \mathrm{~g} \mathrm{~kg}^{-1}, \mathrm{v}$ dinatriumfosfátech $0.22-2,47 \mathrm{~g} \mathrm{~kg}^{-1}, \mathrm{v}$ pyrofosfátech 1,97 až $3,86 \mathrm{~g} \mathrm{~kg}^{-1}$ a v amoniumdihydrogenfosfátu $0,21 \mathrm{~g} \mathrm{~kg}^{-1}$. Stanovení je rychlé, jednoduché a dostatečně přesné. Metody mưže být použito ke kontrole obsahu fluoridů v minerálních krmných fosfátech.

\section{Определение содержания фторидов в кормовых фосфатах}

Проводилась разработка метода определения содержания фторидов в минеральных кормовых фосфатах с помочью фтористого ионно селективного электрода. С помощью настоящего метода далее определялись следующие средние величины содержания фторидов: в дикальцийфосфатах 0,07-1,80 г $\mathrm{k \Gamma}^{-1}$, в динатрийфосфатах $0,22-2,47 \mathrm{r} \mathrm{kг}^{-1}$, в пирофосфатах $1,97-3,86 \mathrm{r} \mathrm{kг}^{-1}$ и в аммонийдигидрогенфосфате $0,21 \mathrm{r} \mathrm{kr}^{-1}$. Определение отличается быстротой, простотой и достаточной точностью. Метод можно использовать для контроля фторидов в минеральных кормовых фосфатах.

\section{References}

DAVISON, A. W. - BLAKEMORE, J. - WRIGHT, D. A.: A re-examination of published data on the fluoride content of pastures. Envir. Pollut., 10, 1976: 209-215.

GREENWOOD, D. A. et al.: Fluorosis in cattle. Special Report 17, Agricultural Experiment Station Utah State University, Logan 1964: 36.

GRIFFITH-JONES, W.: Fluorosis in dairy cattle. Vet. Rec., 200, 1977: 84-89.

HAPKE, H. J.: Toxikologie für Veterinärmediziner. Stuttgart, Ferdinand Enke Verlag, 1975: $160-165$.

JAGOS, P. et al.: Fluoroza skotu. Veterinářství, 27, 1977: 12-14.

LAING, K. R.: Note on fluoride analysis of superphosphates. N. Z. J. Sci., 19, 1976: 401.

ROSENQUIST, J. B.: Effect of supply and withdrawal of fluoride. Acta path. microbiol. scand., A, 83, 1975: 628-632.

SAID, A. N. et al.: High fluorine water to wether sheep maintained in pens. Nord. VetMed., 29, 1977: $172-180$.

SCHWARZ, K.: Recent dietary trace element research, exemplified by tin, fluorine, and silicon. Fedn Proc. Fedn Am. Socs exp. Biol., 33, 1974: 1748-1757.

TORMA, L.: Collaborative study of ion selective electrode method for the direct determination of fluoride in feeds. J. Ass. off. analyt. Chem., 58, 1975: 477-481.

TUSL, J.: Stanovení fluoru $\mathrm{v}$ čistých sloučeninách fosforu alizarinkomplexonátem lanthanitým po mikrodestilačním oddělení. Chem. Listy, 62, 1968: 839-843.

TUŚL, J.: Přímé stanovení fluoru ve fosfátech fluoridovou elektrodou. Chem. Listy, 64, 1970: $322-324$.

VANDEPUTTE, $M$. et al.: Comparison of methods for the determination of fluorine in plants. Z. analyt. Chem., 282, 1976: 215-216. 